\title{
Socioeconomic development indicators of Tocantins state, Brazil, a peripheral region of Amazon
}

\author{
Nilton Marques Oliveira ${ }^{1}$ e Udo Strassburg ${ }^{2}$
}

1 Doutor em Desenvolvimento Regional e Agronegócio pela UNIOESTE, Toledo - PR, Mestre em Economia Aplicada pela UFV e Economista pela UEM. Professor do Programa de Pós-graduação em Desenvolvimento Regional e do curso de Ciências Econômica da Universidade Federal do Tocantins - UFT. Bolsista do Programa "Novos Pesquisadores da UFT" (Propesq/UFT), Brasil. E-mail: E-mail: niltonmarques@uft.edu.br

2 Doutor em Desenvolvimento Regional e Agronegócio na Unioeste - Toledo - PR, Professor do Curso de Ciências Contábeis da Unioeste, Cascavel-PR, Brasil. E-mail: udo.strassburg@unioeste.br

\begin{abstract}
This study primary aimed to analyze the socioeconomic development indicators in Tocantins State, a peripheral region of Amazon, related to the first decade of this century. The used data are from Instituto Brasileiro de Geografia e Estatística-IBGE (Brazilian Institute of Geography and Statistics), Tocantins State, and the United Nations Development Programme (UNDP). Data are related to birth rate, gross death rate, infant death rate, Human Development Index (HDI), literacy rate, fertility rate, per capita Gross Domestic Product (GDP). Results suggest that the Tocantins State occupies the median position in socioeconomic development in the Brazilian North region, having shown progress in some indicators, but still has a long way for reaching satisfactory standard of economic development.
\end{abstract}

Keywords: Socioeconomic Development; Amazon Region; Human Development

\section{Caracterização dos indicadores de desenvolvimento socioeconômico em uma região periférica da Amazônia: Tocantins}

RESUM 0: 0 objetivo central desse artigo foi analisar indicadores de desenvolvimento socioeconômico em uma Região Periférica da Amazônia do Estado do Tocantins, na primeira década do século XXI. Os dados utilizados são oriundos do Instituto Brasileiro de Geografia e Estatística (IBGE), Governo do Estado do Tocantins, Programa das Nações Unidas para o Desenvolvimento (PNUD). Utilizando dados como índice de natalidade, índice de mortalidade bruta e infantil, Índice de Desenvolvimento Humano, taxa de alfabetização, taxa de fecundidade, Produto Interno Bruto (PIB) per capita. Os resultados sugerem que o Estado do Tocantins ocupa posição mediana em desenvolvimento socioeconômico na região Norte, tendo apresentado evolução em alguns indicadores, mas ainda tem muito que avançar para chegar ao padrão satisfatório de desenvolvimento econômico.

Palavras-chaves: Desenvolvimento Socioeconômico; Região Amazônica; Desenvolvimento Humano.

\section{INTRODUCTION}

The main objective of this paper is a characterization of socioeconomic development indicators in Tocantins State, a peripheral region of Amazon, related to the first decade of this century, comparing its indicators with the ones of the Brazilian Northern Region. 
This paper is justified because there are just a few studies concerning this specific region of Brazil. Thus, this study contributes to the analysis of economic indicators getting information about the real needs of Tocantins population.

The basic hypothesis that guides this study focuses on economic and social data from the Tocantins State, taking into account its growth and development presented in the 2000s. Tocantins is a particular and historical result of capitalist development process in Brazil, as well as the agricultural frontier expansion in the Amazon; it is not an isolated space, but an integral and interdependent part of the capitalist economy.

Aiming to understand the economic growth of this state, the question that drives this work is: "Is it possible that the economic growth of the newest state of the Brazilian Federation results in social welfare and access to education, health, sanitation, and employment for the population of Tocantins?"

Tocantins is one of the Brazilian states that showed the most intense growth process, both demographic and economic with rates much higher than the national averages. The migratory movement is still in a continuous process evidencing that the Tocantins State and the city of Palmas are attractive for people from neighboring regions.

The population of the Tocantins had an average growth of $22.5 \%$ from 2000 to 2010; and its gross domestic product (GDP) grown more than the other states, showing 74.2\% in the accumulated from 2002 to 2010 (IBGE, 2012). Regarding the creation of formal employment, in 2000, the state had 106,040 job positions; in 2011, this number rose to 242,769, a growth over $128 \%$ (M inistério do Trabalho e Emprego (MTE), M inistry of Labour and Employment, 2012).

To be able to make a comparison about the differential development among countries, regions, and states, it is necessary to analyze variables such as per capita income, education level in general, infant mortality ratio, basic sanitation, population growth rate, and other variables that will be discussed here.

Santos et al. (2010) made similar studies and analyzed the economic and social indicators for the state of Mato Grosso do Sul, Brazil. Results showed that Mato Grosso do Sul occupies a prominent position in socioeconomic development in the Midwest region of Brazil, with the second best Human Development Index (HDI), just behind the Federal District of Brazil. Lower fertility rates, infant mortality, and higher life expectancy at birth were observed in Mato Grosso do Sul, when compared to the average of the Midwest region and the whole country.

All previous indicators can be summarized by the Human Development Index $(\mathrm{HDI})^{1}$ prepared by the United Nations Development Programme (UNDP).

Thus, the study about socioeconomic indicators is relevant, which may show if the

\footnotetext{
${ }^{1}$ The HDI (Human Development Index) ranges from 0 to 1 (the closer to 1, the higher the human development). The three analyzed variables are health, education, and income. The HDI is divided into four categories, (1) $25 \%$ with higher HDI are the states with very high Human Development; (2) the following quartile represents the states with high development (including the whole Brazil); (3) the third group belongs to the medium; and (4) the $25 \%$ worst are the states with the low human development (UNDP, 2011).
} 
state and society are investing resources for improving the population life quality. It is worth to consider that the Tocantins State is still an economy in formation, but has economic potential especially in Palmas, its capital city.

The economic growth of Palmas follows the same performance presented by the State with an average growth of 14.4\% of GDP from 2000 to 2010 (IBGE, 2012).

This study is divided into six sections. Besides this introduction (Section 1), Section 2 presents the historical characterization of Tocantins. Section 3 describes the theoretical framework and the Section 4 describes the methodological procedures. Section 5 presents the analysis of the socioeconomic development indicators of Tocantins. The concluding remarks summarize the work (Section 6).

\section{HISTORICAL CHARACTERIZATION OF TOCANTINS}

The history of Tocantins State is dating back to the period of Brazil Independence. According to Duarte et al. (2010), to facilitate the administration, the justice application, and particularly encourage settlement and development of the navigation of Araguaia and Tocantins rivers, a Permit was created dividing the Captaincy of Goiás in two counties (regions) or what today might be called in thesis municipalities: North County and South County.

According to Barbosa et al. (2004), this act marked definitely disharmony between the North and South of Goiás. Great defender of regional interests, the Judge Joaquim Theotônio Segurado was appointed administrator, becoming one of the emancipation forerunners of the Tocantins State.

To Segurado, the justifications for separation northern region from the southcentral region of Goiás State were aspects of economic, political, administrative, and geographical nature. In this sense, according to Parente (1999), since the beginning, the northern portion of Goiás was isolated by legal measures, as well as by the geographical position not suitable for agricultural production in relation to other consumer centers, and this affirmative has not ceased to be true, because the wealth was concentrated in the southern region of Goiás in detriment of the northern region of the state.

Discussions aimed for the emancipation of Tocantins came back in the 70s after numerous struggles of the separatist movement, but there was no interest nor resources for the creation of a new state.

Tocantins State was created by the National Constituent Assembly in Article 13 of the Temporary Constitutional Provisions Act of the Constitution of the Federative Republic of Brazil, promulgated on October 5, 1988. And, thus, the northern Goiás became emancipated and is now called Tocantins.

As seen, the state division was a longstanding demand of the people of former northern Goiás. Few socioeconomic changes occurred in the $90 \mathrm{~s}$, because the state was still consolidating investments in basic infrastructure, both at the newly inaugu- 
rated Palms capital city as well as in other cities.

Economic growth and urbanization of Tocantins really has only emerged in the 2000 s. The productive sectors undergo a process of expansion that may cause to occupy a more relevant position on the national scene in the coming years. In general, both the Tocantins as Palmas have experienced strong economic growth since their creation, bringing a number of opportunities in the agricultural, industrial, and services sectors.

Some of these opportunities are the construction of the North-South Railway and the construction of the Hydroelectric Power Plant Luís Eduardo Magalhães (902.5 MW), in Lajeado municipality. There is also the investment possibility in Tocantins Waterway enabling the outflow of 56 million tons of grain and inputs, connecting the North to M idwest regions of the country.

\section{THE THEORY OF ECONOMIC DEVELOPM ENT: SOME CONSIDERATIONS}

In this section, some theories of development will be discussed and then some concepts will be redeemed. Therefore, initially, the definition of Kuznetz (1983) will be considered. For him, the development is in essence a process of economic growth along with improvement of the population living standard, as well as by fundamental changes in the structure of their economy.

In his pioneering work, "Economic Growth and Income Inequality" (1995), Kuznetz studied the development of many countries. He found that very poor countries with very low per capita income showed the Gini indexes less unequal than countries that had just started their development process. The "law of Kuznetz" is a labeled and known expression; according to it, the underdeveloped countries in the developing process inevitably have a phase with accentuated income inequalities; then, with the development, they go to a phase when income inequality decreases until reaching a more egalitarian index as developed countries. This fact means that the economic growth process shows an inverted U-shaped curve for the relationship between index of income inequality and per capita income growth rate.

For Hirschman (1961) and Furtado (1987), the development depends on the many factors, including: (i) past history; (ii) geographical location; (iii) population; (iv) culture; (v) territorial extension; and (vi) natural resources.

Furtado (1986) complements stating that economic growth is only related to the increase of actual production, not modifying the production functions. Economic development is related to economic growth, but it is much more than a simple growth, changing a more complex structure, the social and economic forms of social labor division, satisfying the collective needs.

Hirschman (1961) defines economic development as a broad event and its occurrence involves increasing the life quality levels. To achieve this life quality, some prerequisites are essential: (a) natural resources, (b) energy production sources, (c) ex- 
istence of qualified human resources, (d) administrative capacity, and (e) technologies.

Another theory is the cumulative growth or cumulative circular causation developed by Myrdal (1968). By this theory and concepts, he states about a virtuous or vicious cycle that can occur in an ascendant and descendant way, i.e., some events sequence triggering other events in a cumulative and propellant way. He uses this concept in both the economic and social fields.

According to M yrdal (1968), the production expansion of an urban center generates benefits to adjacent localities, employing large numbers of workers and stimulating the market for consumer goods. He states that regional inequalities are worsen to the extent in which the country is poorer; and that the higher the development level, the stronger the propellant effect, considering the social and economic conditions that the richest countries have.

The Growth Poles Theory developed by François Perroux explains the investments concentration for a better utilization of linkage effects. Perroux (1978) argues that the starting point for chaining the growth process is the insertion of a propelled industry that is capable to spread the linkage effects toward the polarized activities. Such insertion into a regional system will raise positive and negative effects on the receiving region. As such effects will be concentrating, propellent activity will become a propellant pole to region's economy. The development will depend on the level and quality of positive and negative effects.

This study has no intention to extend the development definitions; it aims to present some theories that underlie the growth and development of a country. Hereafter, the methodological procedures are presented.

\section{METHODOLOGICAL PROCEDURES}

For this work, publications of IBGE, Government of Tocantins State, as well as other sources such as UNDP, websites, and books were used. To characterize the Tocantins State, an extensive literature was reviewed to know about the region under analysis. This process is indispensable for analyzing the characterists for knowing well a certain region.

To make the socioeconomic characterization, data were collected about income, population, infant mortality, and illiteracy in Brazilian Northern region and, specifically, in the Tocantins State.

The Brazilian Northern region has about $3,853,575.6 \mathrm{~km}^{2}$, corresponding to approximately $45.3 \%$ of the entire Brazilian territory. Around $7.2 \%$ of the territorial extension of the Brazilian Northern Region belongs to Tocantins State that measures $277,621.9 \mathrm{~km}^{2}$ (Table 1). 
Table 1 - Population density and area of Brazil, from the Northem Region and the State of Tocantins

\begin{tabular}{ccc}
\hline Local & Total area of territorial units $\left(\mathrm{km}^{2}\right)$ & Share $(\%)$ \\
\hline Brazil & $8.502 .728,3$ & - \\
North & $3.853 .575,6$ & 45,3 \\
Tocantins & $277.621,9$ & 7,2 \\
\hline
\end{tabular}

Source: IBGE - Demographic Census (2010)

Tocantins State has 139 municipalities and a population of 1,373,551 inhabitants (2010), 85.9\% urbanization rate, and demographic density of 4.95 inhabitants $/ \mathrm{km}^{2}$. The state capital city is Palmas with a population of 223,817 inhabitants. The state's characteristics are: (1) Tocantins and Araguaia Rivers, the main watersheds; (2) around 5,000 km of paved roads; (3) distance of $899.5 \mathrm{~km}$ between the extreme points in the North-South direction, and $615.4 \mathrm{~km}$ in the East-West direction; (4) agricultural potential of 16 million hectares of suitable soils for agriculture; and (5) vegetation composed of $87 \%$ Cerrado and $13 \%$ the Amazon Rainforest (IBGE, 2010).

\section{ANALYSIS OF SOCIOECONOMIC DEVELOPM ENT INDICATORS OF TOCANTINS STATE}

Table 2 shows the urban and rural total population of Brazil, Northern Region, and Tocantins State, from 2000 to 2010. The simple conclusion from this table is the urban population predominance for the three federative entities.

Table 2 - Total Population - Urban and rural residents (thousand people) in Brazil, Northern Region and the State of Tocantins, between 2001 and 2010

\begin{tabular}{cccccccccc}
\hline \multirow{2}{*}{ Year $\left(^{*}\right)$} & \multicolumn{3}{c}{ Brazil } & \multicolumn{3}{c}{ North } & \multicolumn{3}{c}{ Tocantins } \\
\cline { 2 - 9 } 2001 & 170955 & 143378 & 27577 & 9830 & 9486 & 344 & 1194 & 850 & 344 \\
2002 & 173501 & 145913 & 27588 & 10200 & 9870 & 330 & 1211 & 881 & 330 \\
2003 & 175954 & 148256 & 27698 & 10611 & 10275 & 336 & 1228 & 893 & 336 \\
2004 & 181687 & 150689 & 30998 & 14300 & 10567 & 3734 & 1244 & 889 & 355 \\
2005 & 183881 & 152138 & 31743 & 14573 & 10909 & 3665 & 1260 & 896 & 364 \\
2006 & 186021 & 154751 & 31269 & 14838 & 11293 & 3545 & 1275 & 945 & 331 \\
2007 & 188029 & 156763 & 31266 & 15085 & 11616 & 3469 & 1289 & 948 & 342 \\
2008 & 189953 & 159095 & 30858 & 15327 & 11953 & 3374 & 1303 & 974 & 329 \\
2009 & 191796 & 161041 & 30755 & 15555 & 12125 & 3430 & 1316 & 979 & 337 \\
2010 & 190721 & 160879 & 29842 & 15865 & 11663 & 4202 & 1383 & 1090 & 293 \\
\hline
\end{tabular}

Source: IBGE (2010) - National Research by Household Sample $(*)$ estimates years: 2001-2009

Table 3 shows the annual urbanization rate for the same segments. In 2000, the country had an urbanization rate of $81.35 \%$, which increased to $84.35 \%$ in 2010 . The urbanization rate in the Brazilan Northern region from 2000 to 2010 rose from $69.9 \%$ to $73.5 \%$. For Tocantins State, the urbanization rate rose from $74.3 \%$ in 2000 to $78.8 \%$ in 2010. Tocantins presents urbanization rate higher than Northern region, but lower than Brazil. It is evident, therefore, that the country in whole is more urbanized and the population living in rural areas are decreasing more and more. This deruralization 
may be related to the intensive agriculture mechanization in the field and/or public services that cities can provide to their people such as education, health, employment, income, life quality.

Table 3 - urbanization of Brazil, North and Tocantins - 2000-2010

\begin{tabular}{cccc}
\hline Year & Brazil & North & Tocantins \\
\hline 2000 & 81,33 & 69,92 & 74,31 \\
2001 & 83,87 & 73,37 & 71,19 \\
2002 & 84,10 & 74,91 & 72,75 \\
2003 & 84,26 & 75,32 & 72,72 \\
2004 & 82,94 & 73,90 & 71,46 \\
2005 & 82,74 & 74,86 & 71,11 \\
2006 & 83,19 & 76,11 & 74,12 \\
2007 & 83,37 & 77,00 & 73,55 \\
2008 & 83,75 & 77,99 & 74,75 \\
2009 & 83,96 & 77,95 & 74,39 \\
2010 & 84,35 & 73,51 & 78,81 \\
\hline
\end{tabular}

Source: IBGE / 2000 and 2010 Censuses

The more the population grows, the greater the demands to meet their basic needs and improve the development indicators (SOUZA, 2005). Therefore, it is necessary to calculate the population growth rates. Table 4 shows the rates for Brazil, Northern region, and Tocantins State, from 2001 to 2010. Tocantins presented an annual growth rate of 1.34, higher than $1 \%$ for Brazil, but lower than 1.88 for the Northern region.

Table 4 - Population Growth Rate: Brazil, North and Tocantins - 2001-2010

\begin{tabular}{cccc}
\hline Year & Brazil & North & Tocantins \\
\hline $2001-2010$ & 1,00 & 1,88 & 1,34 \\
\hline
\end{tabular}

Source: IBGE (2010)

Table 5 shows the birth rate for the above mentioned federative units from 2000 to 2008, comprising the number of live births per 1,000 inhabitants; Tocantins State had a birth rate of 26.9 in 2000, which declined to 20.5 in 2008, a difference of 6.4 higher than the difference of 5.6 in the Northern region and the difference of 4.8 for Brazil. Tocantins State has a birth rate lower than the Northern region, but higher compared to the national rate. It is observed that the birth rate has been declining over the analyzed years. The largest birth rate reduction occurred in Tocantins State, in which the rate decreased from 26.9 live births per 1,000 inhabitants in 2000 to 20.5 in 2008. 
Table 5 - Birth rates for Brazil, North and Tocantins - 2000-2008

\begin{tabular}{cccc}
\hline Year & Brazil & North & Tocantins \\
\hline 2000 & 21,2 & 28,8 & 26,9 \\
2001 & 20,1 & 27,5 & 25,8 \\
2002 & 19,5 & 26,5 & 24,6 \\
2003 & 18,8 & 25,3 & 23,4 \\
2004 & 18,5 & 24,2 & 22,4 \\
2005 & 17,7 & 22,6 & 21,4 \\
2006 & 17,1 & 21,7 & 20,5 \\
2007 & 16,6 & 21,3 & 18,4 \\
2008 & 16,4 & 23,2 & 20,5 \\
\hline
\end{tabular}

Source: IBGE / Preliminary demographic projections (2010).

With regard to life expectancy at birth, Table 6 shows the years evolution of life expectancy at birth distributed by gender. In the three federative entities, women had higher expectation compared to man, but there was significant improvement both for men and for women, which indicates a significant improvement in Brazilians' life quality.

TABLE 6 - Life expectancy at birth: Brazil, North and Tocantins - 2000-2009

\begin{tabular}{ccccccc}
\hline Year & \multicolumn{2}{c}{ Brazil } & \multicolumn{2}{c}{ North } & \multicolumn{2}{c}{ Tocantins } \\
\hline & Male & Female & Male & Female & Male & Female \\
\hline 2000 & 66,7 & 74,4 & 66,8 & 72,4 & 67,2 & 71,3 \\
2001 & 67,1 & 74,7 & 67,1 & 72,7 & 67,4 & 71,6 \\
2002 & 67,4 & 75,0 & 67,4 & 73,0 & 67,7 & 72,0 \\
2003 & 67,7 & 75,3 & 67,7 & 73,3 & 68,0 & 72,3 \\
2004 & 68,0 & 75,6 & 68,0 & 73,7 & 68,3 & 72,6 \\
2005 & 68,4 & 75,9 & 68,2 & 74,0 & 68,5 & 73,0 \\
2006 & 68,7 & 76,2 & 68,5 & 74,3 & 68,8 & 73,3 \\
2007 & 68,8 & 76,4 & 68,8 & 74,6 & 69,1 & 73,6 \\
2008 & 69,3 & 76,8 & 69,1 & 74,9 & 69,3 & 73,9 \\
2009 & 69,6 & 77,1 & 69,3 & 75,1 & 69,6 & 74,2 \\
\hline
\end{tabular}

Source: IBGE / Preliminary population projections (2010).

To the mortality gross rate (per 1,000 inhabitants) in the three federative units, the woman had a higher expectation compared to man, but there was significant improvement both for men and for women, which indicates a significant improvement in Brazilians' life quality. Table 7 shows the Tocantins State with higher mortality gross rate than the Northern Region in all analyzed years; however, this rate is lower than the national average. It is noted that there is a regression rate over the years, which can be directly related to the better nutrition, better basic sanitation conditions, among other variables. 
Table 7 - Gross Mortality Rate for Brazil, North and Tocantins - 2000-2008

\begin{tabular}{l|ccc}
\hline \multicolumn{1}{l}{ Year } & Brazil & North & Tocantins \\
\hline 2000 & 6,4 & 5,3 & 5,9 \\
2001 & 6,3 & 5,2 & 5,9 \\
2002 & 6,3 & 5,1 & 5,8 \\
2003 & 6,2 & 5,0 & 5,7 \\
2004 & 6,2 & 5,0 & 5,7 \\
2005 & 6,0 & 4,9 & 5,6 \\
2006 & 6,0 & 4,9 & 5,6 \\
2007 & 6,0 & 4,8 & 5,5 \\
2008 & 6,1 & 4,8 & 5,1 \\
\hline
\end{tabular}

Source: IBGE / Preliminary demographic projections (2010).

There was an increase in the country from $56.5 \%$ in 2000 to $61,8 \%$ in 2010 for basic sanitation: sewer network or septic tank connected to the general sewage system, water supply from the general water supply system, and garbage collected directly or indirectly by the cleaning services. In cities with up to five thousand inhabitants, the rates increased from $21.7 \%$ in 2000 to $30.8 \%$ in 2010. In cities with more than 500,000 inhabitants, the percentages were $79.7 \%$ in 2000 , rising to $82.5 \%$ in 2010 (IBGE, 2011).

Analyzing the data for the Northern region of the country, only $22.4 \%$ of households had adequate sanitation conditions in 2010, while in the Southeast region of the country the proportion was $82.3 \%$. For the Tocantins State, this percentage rises to about $25 \%$ of basic sanitation. It can be concluded that it is still poor basic sanitation in the country in whole and even more critical in Northern Brazil.

Analyzing the infant mortality rate, Table 8 shows the state having the highest rate when compared to the North and whole Brazil. In Tocantins, in 2007, for every thousand live births, 27.3 have died. In the North and in whole Brazil, 24.3 and 25 have died, respectively, per thousand live births in 2007. Reduction in infant mortality rate is noted in the subsequent years, 2009 and 2010, both in the Tocantins State and in the Brazilian larger region and federation. From 2007 to 2009, there was a reduction of $6.9 \%$ in the infant mortality rate of Tocantins, 5.9 in the Northern region, and 5.5 in the national infant mortality rate. This reduction can be attributed to increased levels of political and individual freedoms and the female education level.

Table 8 - Infant mortality rate for Brazil, North and Tocantins per 1,000 live births: 2000 and 2009

\begin{tabular}{cccc}
\hline Year & Brazil & North & Tocantins \\
\hline 2000 & 30,1 & - & - \\
2001 & 29,2 & - & - \\
2002 & 28,4 & - & - \\
2003 & 27,5 & - & - \\
2004 & 26,6 & - & - \\
2005 & 25,8 & - & - \\
2006 & 25,1 & - & - \\
2007 & 24,3 & 25,0 & 27,3
\end{tabular}




$\begin{array}{llll}2008 & 23,3 & 24,2 & 26,4 \\ 2009 & 22,5 & 23,5 & 25,6\end{array}$

Source: IBGE, Directorate of Research, Department of Population and Social Indicators, Management Studies and Analyses of Demographic Dynamics, Project UNFPA / BRAZIL (BRA/02/P02) - Population and Development, Systematic measures and sociodemographic indicators derived from the projection of population by sex and age, by demographic method, the Major Regions and Federation Units, for the period 19912030.

Analyzing the fertility rate according to the situation of the rural or urban residence, it was observed that, from 2007 to 2009, the Northern Region had the highest fertility rates, especially in rural areas, followed by Tocantins and Brazil. This indicator can also be directly related to the female education level and to the awareness policies by government (Table 9 ).

Table 9 - Total fertility rate by household situation Brazil, Tocantins and Northem Region: 2000 and 2009

\begin{tabular}{cccccccccc}
\hline \multirow{2}{*}{ Year } & \multicolumn{3}{c}{ Brazil } & \multicolumn{3}{c}{ North* } & \multicolumn{3}{c}{ Tocantins** } \\
\cline { 2 - 10 } & Total & Urban & Rural & Total & Urban & Rural & Total & Urban & Rural \\
\hline 2000 & 2,38 & 2,18 & 3,49 & - & - & - & - & - & - \\
2001 & 2,33 & 2,18 & 3,42 & - & - & - & - & - & - \\
2002 & 2,26 & 2,11 & 3,25 & - & - & - & - & - & - \\
2004 & 2,13 & 1,96 & 3,14 & - & - & - & - & - & - \\
2005 & 2,06 & 1,93 & 3,02 & - & - & - & - & - & - \\
2006 & 1,99 & 1,86 & 2,86 & - & - & - & - & - & - \\
2007 & 1,95 & 1,81 & 2,74 & 2,6 & 2,36 & 3,61 & 2,26 & 2,4 & 2,87 \\
2008 & 1,89 & 1,75 & 2,4 & 2,37 & 2,14 & 3,39 & 2,07 & 1,99 & 2,53 \\
2009 & 1,94 & 1,81 & 2,73 & 2,51 & 2,23 & 3,47 & 2,6 & 2,24 & 3,23 \\
\hline
\end{tabular}

Source: IBGE (2010) Research Directorate, Department of Population and Social Indicators, Management Studies and Analyses of Demographic Dynamics.

$(*)(* *)$ There is no data available for the North and Tocantins between 2000 and 2006 .

When observing the education level (Table 10), Tocantins State has the lowest literacy rate when compared to the Northern region and Brazil. In 2007, the literacy rates for men and women in the Tocantins State were $84.3 \%$ and $87.2 \%$, respectively. For the region, this indicator can also be directly related to the female education level and awareness policies by government (Table 9); in North, the literacy rate in 2007 was $90 \%$ for women and $88.3 \%$ for men; and in Brazil, the rates for men and women were, respectively, $89.8 \%$ and $90.25 \%$. It can be observed also reduction in the literacy rate for women from 2007 to 2008, both in the North and in the Tocantins State. In Brazil, this rate was maintained for two years, but there was increased literacy rates for both men and women from 2007 to 2009 in Tocantins State, in the North, and in the country. 
Table 10 - Literacy rate of persons 15 years or older by sex Brazil, Tocantins and Northern Region: 2001 and 2009

\begin{tabular}{c|c|c|c|c|c|c}
\hline Year & \multicolumn{2}{|c|}{ Brazil } & \multicolumn{2}{c|}{ North* } & \multicolumn{2}{c}{ Tocantins** } \\
\hline & Male & Female & Male & Female & Male & Female \\
2001 & 87,5 & 87,7 & - & - & - & - \\
2002 & 88 & 88,3 & - & - & - & - \\
2004 & 88,3 & 88,6 & - & - & - & - \\
2005 & 88,4 & 88,8 & - & - & - & - \\
2006 & 88,7 & 89,2 & - & - & - & - \\
2007 & 89,4 & 89,9 & - & - & - & 87,2 \\
2008 & 89,8 & 90,2 & 88,3 & 90 & 84,3 & 86,8 \\
2009 & 89,8 & 90,2 & 88,8 & 89,7 & 84,5 & 87,9 \\
\hline
\end{tabular}

Source: IBGE, National Household Survey 1992/2009.

$(*)(* *)$ There is no data available for the North and Tocantins between 2001 and 2006.

The Human Development Report 2011 shows that Brazil is part of a select group of only 36 of the 187 countries that have risen in the rankings from 2010 to 2011, according to data recalculated for the new base of this year. In the Brazilian case, this HDI evolution from last year to this year had a greater push of health dimension measured by life expectancy - responsible for $40 \%$ of the increasing rate. Each of the two dimensions that comprise the HDI, education and income, correspond to $30 \%$ of this development (UNDP, 2011).

Table 11 - Human Development Index (HDI) for Brazil, North and Tocantins: 2000, 2005 and 2010

\begin{tabular}{c|c|c|c}
\hline Year & Brazil & North & Tocantins \\
\hline 2000 & 0,665 & 0,727 & 0,710 \\
\hline 2005 & 0,692 & 0,766 & 0,756 \\
\hline 2010 & 0,715 & 0,787 & 0,766 \\
\hline
\end{tabular}

Source: UNDP, 2010 - Human Development Report; IBGE (2010) and IPEA (2010).

Table 11 shows the HDI data for 2000, 2005, and 2010. In 2000, the country had an $\mathrm{HDI}$ of 0.665 , advancing to 0.718 after a decade. To the North Region, this index was 0.727 , rising to 0.787 in 2010. For the Tocantins State, the index rose from 0.710 in 2000 to 0.766 in 2010. It can be concluded that the country is moving in the social and economic indicators, both in the North and in the Tocantins State, and this advancement is reverting in life quality and social welfare.

Regarding to income analysis, it is noted that the GDP of the Tocantins State in 2010 represents about $0.46 \%$ of national GDP and about $8.56 \%$ of GDP in the North, while the North is about $5.34 \%$ of national GDP (Table 12 ).

Table 12 - Gross Domestic Product (GDP) at market prices (U.S. \$ 1,000,000) for Brazil, North and Tocantins

\begin{tabular}{c|c|c|c|c}
\hline & 2007 & 2008 & 2009 & 2010 \\
\hline Brazil & 2661345 & 3032203 & 3239404 & 3770085 \\
\hline North & 133578 & 154703 & 163208 & 201511 \\
\hline Tocantins & 11094 & 13090 & 14571 & 17240 \\
\hline
\end{tabular}

Source: IBGE - Regional Accounts (2010). 
The per capita GDP has been used as the main indicator of economic growth. In 2009, the per capita GDP of Tocantins was higher than average GDP in the Northern Region, respectively, $\mathrm{R} \$ 11,278$ (eleven thousand, two hundred, and seventy-eight reais) and $\mathrm{R} \$ 10,626$ (ten thousand, six hundred, and twenty-six reais), but these GDP's are lower than the national average, $R \$ 16,918$ (sixteen thousand, nine hundred, and eighteen reais) (expressed in Brazilian currency; $R=$ Real; plural = reais) (Table 13).

Table 13 - GDP per capita at market prices to Brazil, North and Tocantins -2007 to 2009

\begin{tabular}{c|c|c|c|c}
\hline & 2007 & 2008 & 2009 & 2010 \\
\hline Brazil & 14465 & 15992 & 16918 & 19016 \\
\hline North & 9135 & 10216 & 10626 & 12701 \\
\hline Tocantins & 8921 & 10223 & 11278 & 12461 \\
\hline
\end{tabular}

Source: IBGE (2010)

Table 13 shows the per capita GDP for Brazil, North, and Tocantins State from 2007 to 2010 . In the accumulated, the country had a GDP growth of $31.46 \%$, the Northern Region had $39.04 \%$, and the Tocantins State had the best rate, $39.53 \%$. When calculating the average annual GDP rate, the Tocantins State had a rate of 3.07, the Northern Region, 3.0\%, and Brazil had a rate of $2.52 \%$.

This per capita GDP growth in the Tocantins State can be assigned to works in the infrastructure area, for example, advances in the works of the North-South Railway, the agriculture expansion in the state, and investment in waterway and BelémBrasilia highway.

According to IBGE data (2010), Tocantins State experienced the largest growth in volume from 2002 to 2010 with an annual average of $14.2 \%$ and $74.2 \%$ in the accumulated. The growth national average rate was $7.5 \%$ compared to 2009 and $37.1 \%$ in the accumulated.

\section{FINAL THOUGHTS}

The main objective of this paper was to analyze the socioeconomic development indicators of the Tocantins State, making a comparison with the national average and the Northern Region, considering the State historical context.

Some considerations on the indicators show that both Brazil and the Tocantins State are more urbanized with a rate of $84.3 \%$ and $78.7 \%$ of urbanization, respectively. The State presented an annual growth rate of $1.34 \%$, higher than the rate of Brazil, which was 1\%, but lower than the North's rate. The birth rate for the State rose from 26.9 in 2000 to 20.5 in 2008. Life expectancy has increased in the three analyzed federative units.

The HDI recorded in the country was 0.665 in 2000; after a decade, it rose to 0.718 . To the North region, this index rose from 0.727 in 2000 to 0.787 in 2010 . For 
the Tocantins State, HDI rose from 0.710 in 2000 to 0.766 in 2010.

When analyzing the GDP of Tocantins from 2002 to 2010, it was noted that the State had the highest growth, $74.2 \%$ in the accumulated. The share of GDP of the Tocantins State in 2010 represents about $0.46 \%$ of national GDP and about $8.56 \%$ of GDP in the North region, while the North region represents about $5.34 \%$ of the national GDP. Regarding to per capita GDP, the Tocantins State recorded an average annual growth of 3.07, the Northern Region had 3.0\%, and Brazil had 2.52\%. Therefore, Tocantins State showed great performance.

The presented data allow us to conclude that the Tocantins State occupies the median position in socioeconomic development in the North region of the country. There were improvements in some indicators, but there is still a long way for reaching satisfactory standard of economic development.

There is a hypothesis that the Tocantins State is a historical result from the capitalist development process in Brazil, as well as resultant from the expansion of the agricultural frontier in the Amazon, which is not an isolated space, but an integral and interdependent part of the capitalist economy. Regarding the raised question, it can be stated that the newest federative unit of Brazil is so still limited, investing in the life quality of its population. This study does not exhaust the subject matter contained herein, recommending further studies for other regions of the country.

\section{REFERENCES}

AJARA, César; BARBOSA, Jaci Gelabert; BEZERRA, Vera Maria D’Avila C. o Estado de Tocantins: reinterpretação de um espaço de fronteira. Revista Brasileira de Geografia. Rio de Janeiro, 53 (4): 5 - 48, p 5 - 48, out. /dez. 1991.

BARBOSA, Altair Sales; GOMES, Antônio Teixeira; NETO. Amazônia e a Globalização. In: Amazônia: geopolítica na virada do III. Horieste. Geografia: Goiás-Tocantins. 2. ed. Goiânia: Editora da UFG, 2004. 270 p.

DATASUS. Anos de vida esperados, por ano, Segundo Região e UF. Disponível em: $\varangle$ abnet.datasus.gov.br/cgi/idb2010/a11fb.htm>. 2012. Acesso em: 12 mar. 2015.

DATASUS. Anos de vida esperados, por ano, Segundo Região e UF. Disponível em: $\varangle$ đabnet.datasus.gov.br/cgi/idb2010/a11mb.htm>. 2012. Acesso em: 12 mar. 2015.

DATASUS. Número de nascidos vivos por $\mathbf{1 . 0 0 0}$ habitantes, por ano, segundo Região e UF. Disponível em: \abnet.datasus.gov.br/cgi/idb2010/a07b.htm>. 2012. Acesso em: 12 mar. 2015.

DATASUS. Número de mortos por 1.000 habitantes, por ano, segundo Região e UF. Disponível em: $\Varangle a b n e t . d a t a s u s . g o v . b r / c g i / i d b 2010 / a 10 b . h t m>.2012$. Acesso em: 12 mar. 2015.

DATASUS. Proporção (\%) de população urbana segundo Região e UF. 2012 Disponível em: «abnet.datasus.gov.br/cgi/idb2010/a04ufb.htm>. Acesso em: 12 mar. 2015. IBGE. Taxa de Alfabetização das pessoas de $\mathbf{1 5}$ anos ou mais de idade por sexo. 
2012 Disponível em: $\varangle$ www.sidra.ibge.gov.br/bda/tabela/protabl.asp?c $=1187 \& z=t \&$ $0=1 \& i=P>$. 2012. Acesso em: 10 abr. 2015.

IBGE. Área e Densidade Demográfica da unidade territorial. 2012. Disponível em: $<w w w$. sidra.ibge.gov.br/bda/tabela/protabl.asp? $c=1301 \& z=t \& 0=1 \& i=P>$. Acesso em: 10 abr. 2015.

IBGE. Taxa de fecundidade total por situação de domicílio. 2012. Disponível em: $<w w w$. sidra.ibge.gov.br/bda/tabela/protabl.asp? $c=1163 \& z=t \& 0=1 \& i=P>$. Acesso em: 10 abr. 2015.

IBGE. Taxa de mortalidade infantil, por 1.000 nascidos vivos. 2012. Disponível em: $<w w w$. sidra.ibge.gov.br/bda/tabela/protabl.asp? $c=1175 \& z=t \& 0=1 \& i=P>$. Acesso em: 10 abr. 2015.

IBGE. População residente, por situação, sexo e grupos de idade. 2012. Disponível em: $<w w w . s i d r a . i b g e . g o v . b r / b d a /$ tabela/protabl.asp? $c=261 \& z=t \& 0=1 \& i=P>$. Acesso em: 10 abr. 2015.

FURTADO, C. Teoria e política do desenvolvimento econômico. 11 ed. São Paulo: Nacional, 1987.

0 mito do desenvolvimento econômico. São Paulo: Círculo do Livro, 1985.

HIRSCHM AN, A. O. Desenvolvimento por efeitos em cadeia: uma abordagem generalizada. In: SORJ, B. et al. Economia e movimentos sociais na América Latina. São Paulo: Brasiliense, p. 31-79, 1985.

KUZNETS, S. Economic growth and income inequality. American Economic Review, v.45, p. 1-28, 1955.

KUZNETS, S. S. Crescimento econômico moderno: ritmo, estrutura e difusão. São Paulo: Editora Abril (Coleção Os Economistas), 1983.

JORNAL TRIBUNA DO PLANALTO. Tocantins: trajetória de crescimento. 2012 Disponível em: $<w w w$.tribunadoplanalto.com.br/tocantins/10604-tocantins-trajetoria-de-cre scimento>. Acesso em: 10 abr. 2015.

MYRDAL, Gunnar. Teoria econômica e regiões subdesenvolvidas. 3. ed. Rio de Janeiro: Saga, 1972.

M YRDAL, Gunnar. Teoria Econômica e Regiões Subdesenvolvidas. 2. ed. Editora Saga: Rio de Janeiro, 1968.

PARENTE, Temis Gomes. Fundamentos históricos do estado do Tocantins. Goiânia: Ed. Da UFG. 109 p. 1999.

PERROUX, François. O conceito de polo de crescimento. In: FAISSOL, S. Urbanização e regionalização: relações com o desenvolvimento econômico. Rio de Janeiro: IBGE, 1978.

PNUD - Programa das Nações Unidas para o Desenvolvimento. Relatório do Desenvolvimento Humano (RDH). 2011. Disponível em «ttp:// hdrstats.undp.org/en/indica tors/103106. html>. Acesso em: 10 abr. 2015.

SANTOS, R. F.; SCHLINDWEIN, M. M.; SILVA, A. B. M. E. Análise do nível de desenvolvimento socioeconômico do estado de Mato Grosso do Sul. In: 48 Congresso da Soci- 
edade Brasileira de Economia, Administração e Sociologia Rural - SOBER, Tecnologias, Desenvolvimento e Integração Social. Anais... Dourados-MS. 2010.

SOUZA, Nali de Jesus de. Desenvolvimento Econômico. 5. ed. rev. São Paulo: Atlas, 2005.

TOCANTINS, Estado do. Produto Interno Bruto a Preços de mercado per capita do Brasil, segundo Grandes Regiões e Unidade de Federação - 1995-2009. Disponível em: <www.seplan.to.gov.br/seplan/br/download/20111220195554-pib_per_capita_ do_brasil.pdf>. Acesso em: 10 abr. 2015.

TOCANTINS, Estado do. Produto Interno Bruto do Brasil a preços de mercado, Brasil, segundo Grandes Regiões e Unidade de Federação - 1995-2009. Disponível em: $<w w w . s e p l a n . t o . g o v . b r / s e p l a n / b r / d o w n l o a d / 20111220175647$-produto_interno_bru to_do_brasil.pdf>. Acesso em: 10 abr. 2015.

Artigo recebido em 13 de janeiro de 2017. Aprovado em 17 de janeiro de 2017. 